\title{
Normalizing Human-Animal Power Relations Through Media: Zoo Discourses in Turkey
}

\author{
Sezen Ergin Zengin \\ Dr. Araştırma Görevlisi \\ sezene@hacettepe.edu.tr \\ Hacettepe Üniversitesi Edebiyat Fakültesi \\ Orcid: 0000-0001-5927-5357
}

\begin{abstract}
This study examines zoo discourses on media as a convenient site for probing into human-animal power relations. A form of critical discourse analysis is carried out in national daily news discourse focusing on how zoo discourses portray animals through lexical choices, grammatical structures, and discursive strategies of capitalism, hospitality, and conservation. These strategies overall operate to conceal the domination, oppression, and suffering of captive wild animals behind the benevolent image of the zoo institution promoting conservation, education, and recreation. Through language, animals are constructed, on a superficial level, as subjects who enjoy their lives on natural habitats with their families. Yet further analysis reveals a power abuse in which animals are objectified and commodified for an exclusively human agenda. The study concludes that through the naturalizing effect of discourses human dominance over wild animals are never questioned and the zoos grant animals an instrumental value rather than inherent value.
\end{abstract}

Key Words: Zoos, news discourses, critical animal studies, speciesism, critical discourse analysis 


\section{Normalisation des relations de pouvoir entre l'homme et l'animal par le biais des médias: le discours sur les zoos en Turquie}

\section{Résumé}

Cette étude analyse le discours portant sur les zoos dans les médias, qui nous permettent d'analyser les relations de pouvoir entre l'homme et l'animal. L'analyse de discours se concentre sur des textes sélectionnés de la presse quotidienne nationale turque. Cette étude cherche à expliciter comment les animaux sont représentés dans le discours sur les zoos à travers les choix lexicaux, les structures grammaticales ainsi que les stratégies discursives telles que le capitalisme, I'hospitalité et la sauvegarde. Dans l'ensemble, ces stratégies - cachées sous une image bienveillante des institutions zoologiques pour promouvoir la sauvegarde des animaux, l'éducation et la récréation - servent à dissimuler la domination, l'oppression et les souffrances des animaux sauvages. Les animaux sont construits, à travers le langage, comme des sujets qui apprécient leurs habitats naturels avec leur famille. Or, des analyses plus approfondies révèlent que les animaux sont abusés pour satisfaire aux intérêts humains. Dans ce sens, il est donc possible de parler d'un abus de pouvoir. Cette étude conclut qu'en raison du caractère naturalisant des discours, la dominance humaine sur les animaux sauvages n'est jamais remise en cause. De même, la valeur dont les zoos donnent aux animaux n'est pas inhérente mais plutôt instrumentale.

Mots clés : Zoos, discours de la presse, études animalistes, spécisme, analyse critique du discours 


\section{İnsan-Hayvan Arasndaki İktidarın Medya Yoluyla Normalleştirilmesi: Türkiye'deki Hayvanat Bahçeleri Söylemi}

\section{Öz}

Bu çalışma, medyadaki hayvanat bahçesi söylemlerini incelemektedir zira bu söylem, insan-hayvan arasındaki iktidar ilişkilerini araştırmak için uygun bir alan olarak karşımıza çıkmaktadır. Çalışma, ulusal günlük haber söyleminde hayvanat bahçesi söylemleri üzerine bir eleştirel söylem analizi uygulamakta ve özellikle hayvanların, kelime seçimleri, dilbilgisel yapılar ile kapitalizm, misafirperverlik ve koruma gibi söylemsel stratejiler yoluyla nasıl resmedildiğine bakmaktadır. Bu stratejiler temelde hayvanat bahçesi kurumunun koruma, eğitim ve eğlenceyi görev edinen yardımsever imajının arkasında esir yabani hayvanların tahakkümünü, baskılarını ve acılarını gizlemek için kullanıır. Dil aracılığıyla hayvanlar, yüzeysel olarak, aileleriyle birlikte doğal ortamlarında hayatlarının tadını çıkaran özneler olarak inşa edilir. Ancak, detaylı analizler hayvanların, insanlar lehine konular etrafında nesnelleştirildiği ve metalaştırıldığı bir güç istismarı ortaya koymaktadır. Çalışma, söylemlerin doğallaştırıcı etkisiyle, yabani hayvanlar üzerindeki insan egemenliğinin hiçbir zaman sorgulanmadığı ve hayvanat bahçelerinin hayvanlara içkin bir değerden ziyade araçsal bir değer verdikleri sonucuna varmaktadır.

Anahtar Kelimeler: Hayvanat bahçeleri, haber söylemi, eleştirel hayvan çalışmaları, türcülük, eleştirel söylem analizi 


\section{Introduction}

Zoos are among the sites where the power relations between humans and nonhuman animals become apparent. Yet, as with other sites of human-animal struggle, an extreme version of naturalization occurs; thus, any form of power abuse is normalized through various mechanisms informed by the ideology of speciesism. As a result of these mechanisms which manufacture consent over the capture, confinement, trafficking, and killing of wild nonhuman animals (animals now on), the existence of zoos is never questioned and zoo discourses are not challenged.

In mainstream discourses, modern zoos are portrayed as places providing recreation, education, conservation and research (Acampora, 2010, p. 1). This paper, on the other hand, presents an alternative reading of zoos, aiming at unveiling the latent ideology formed by zoo discourses, which naturalizes and legitimizes animal exploitation. To illustrate this, I examine news discourses featuring zoos, paying special attention to how animals in zoos are represented; which relationships between human and animal subjects are reflected and through which discursive themes their captivity is justified. For analyzing the news stories, a form of critical discourse analysis is employed focusing on discursive strategies, lexical choices, grammatical structures, and silence.

This paper aims at answering the following research questions:

- In which ways zoos represent a site for human power over animals?

- How is human dominance naturalized and made to appear normal?

- How do zoo discourses construct reality in a way to sustain the existing state of affairs?

- Which discursive strategies are preferred in zoo discourse? How are they connected to other social realities?

For providing a theoretical background, I look at, in the following section, the history of zoos together with their philosophical foundations and the views of proponents and opponents of the zoo. After that, I discuss the power of media and tightly connected discourse in relation to constructing human-animal realities.

\section{Captive Animals and Zoos}

Zoos can simply be defined as institutions which put animals on display for various reasons among which come to the forefront the aims of recreation, education, and conservation. The history of modern zoos goes back to $18^{\text {th }}$ century Europe, while British and American counterparts were founded in the 19th century (Jamieson, 2006, p. 132). Without a doubt, there have been numerous cases of animal captivity prior to the emergence of zoos, especially as royal menageries serving as a symbol of wealth, glory, power (see Bostock, 2003 and Best, n. d). Similar menageries were found in the palaces of Istanbul in the Ottoman Empire since 16th century (Günergun, 2006, p. 2). Yet, in modern sense, zoos in West 
have gone through several stages in a relatively short period of time as a response to visitor reactions and rising animal rights movements.

The first stage of zoos exhibited, in rows, animals in bare cages often coming from strange lands. The cages clearly demarcated humans and animals, which strengthened the "notions of human power and superiority over the natural world in the age of colonialism and empire" (Hallman and Benbow, 2006, p. 257). Thus, as part of the colonial project, first zoos rested on the connotations of beastliness and savagery taken under control by the civilizing empire (Ritvo, 1990; Malamud, 1998, p. 60). Similar to the colonial mind insisting on the subduing and civilization of the "primitive" people, wild animals were seen as in need of taming or subduing.

Far from the domination-laden cages, the last phase of zoos employs a design of immersion in which zoo-goers feel like they have been transplanted into a completely natural and wild setting (Braverman, 2013). Predominantly portrayed as wildlife centers or natural parks, these zoos aim at breaking away the notions of captivity and sheer entertainment. Modern zoos emphasize species conservation and education more than recreation. For instance, the home page of AZA (Association of Zoos and Aquariums) reads "leaders in animal care, conservation, and family fun" whereas in EAZA's website (European Association of Zoos and Aquaria), themes of education, understanding animal interaction, protecting endangered species and selecting species for specific reasons are foregrounded.

Zoo critics, on the other hand, assert that simple act of confinement in cages has destructive effects on animals (Jamieson, 2006; Francione, 2000; Gruen, 2018). At worst, animals are cramped in barren cages with no physical or mental stimulation, yet even in "good" zoos they "often exhibit neurotic, stress-induced behaviors, such as pacing, head bobbing, weaving back and forth, and throwing feces at humans" (Francione; 2000, p. 23-24). As previously stated, the most recent zoo designs, labeled as natural parks do provide a larger space to animals. Nevertheless, they are still enclosures far from the natural habitats of animals, and thus animals are "prevented from gathering their own food, developing their own social orders, and generally behaving in ways that are natural to them" (Jamieson, 2006, p. 133).

Apart from real animals and sufferings, zoos are, on a perhaps more meaningful level, metaphors of human dominion. Zoos can be read as institutions of power (Mullan and Marvin, 1987). As anthropocentric institutions, zoos serve human interests because although having connections to nature, "zoos are spaces through which 'nature' is transformed into 'culture' (Anderson, 1998, p. 120). Jamieson (2006, p. 142) claims that "zoos teach us a false sense of our place in the natural order". This is done by means of confinement used for separating humans from other animals which, in turn, transforms their bodies into things "there at our pleasure, to be used for our purposes" (p. 142). 
Animals, then, are treated as if they do not have an inherent value - as put forward by Regan (2004). They are converted into beings who serve our ends in the process of becoming "zoo exhibits" which robs them of "their ontological status as beings who live 'for themselves' (Lee, 2005, p. 33). A more substantial transformation runs deeper. Zoos become "domestic spectacles" showcased as "the testaments of human triumph over nature" (Anderson, 1998, p. 34).

Theoretical discussions also apply to the zoos in Turkey, however many zoos in Turkey are far from the immersion style, where cages are still the norm. Zoos, in Turkey, are regulated under the Ministry of Agriculture and Forestry, the General Directorate of Nature Protection and National Parks. There are 32 licensed zoos nationwide ("Yaban Hayatı", n.d), and three of them are members of EAZA. Unfortunately, there is a lack of information on the status of Turkish zoos (Özen, 2016) and an academic indifference. Zoos operate mostly as a public service given by the municipalities as well as commercial enterprises for the private sector.

\section{Media Discourse and the Discursive Construction of Animals}

Animals and their interactions with humans have recently become a study field under the name of human-animal studies1taking insights from various disciplines (see for instance, DeMello, 2012; Taylor, 2012; Waldau, 2013). What is common in this extremely diverse field is the recognition that "humans and animal lives have always been entangled and that animals are omnipresent in human society on both metaphorical and practical, material levels" (Andersson Cederholm et al., 2014, p. 5). Many scholars have pointed out that human-animal relationships have been a severely neglected form of social inquiry (see Bryant, 1979; Kruse, 2002; Myers, 2003). An offshoot of mainstream human-animal studies is the critical animal studies (CAS), an alternative approach with a normative stance that takes a direct approach to the dire plight of animals tackling hierarchical ideologies and aiming at dismantling all structures of exploitation, domination, oppression, torture, killing and power (Best et al., 2007; also see Nocella Il et al., 2013).

Animals have a long history of subordination, roughly starting with domestication and peaking after the enlightenment. With the advent of the industrial revolution and capitalist economy as its background, animals have turned into machines that are expected to run efficiently with maximum output (see Noske, 1997; Nibert, 2002). This social reality operates, without a doubt, through language. Language is a way to construct relationships, giving power to certain groups, denigrating others while denying their access to power and resources (Mayr, 2008, p. 8). These functions of language have come to the forefront with the linguistic turn, and discourses has provided means to probe power relations.

1 Human-animal interactions are increasingly included in academic studies and despite having differences in their approaches some fields such as ecocriticism, anthrozoology, multispecies ethnography and posthumanism are particularly suited for taking the animal to the foreground (see Smart, 2014) 
Central to the analysis of language in social construction is the connection it has to ideology, particularly the ways language sustains powerful ideologies in a society (see Hodge \& Kress, 1993; van Dijk, 1998; Wodak, 1989). Although one can find varying definitions, ideologies can be briefly defined as "shared social representations that have specific social functions for groups" (van Dijk, 1998, p. 191). At the hands of powerful groups, these shared representations are used in order to "reproduce and legitimate their domination" (van Dijk, 1997, p. 25). Yet, following Gramsci, using coercion for dominance will not be successful in the long run, so ideologies most smoothly run when its "workings are least visible" and when they become common sense assumptions that are taken for granted (Fairclough, 1989, p. 84-5). Creating through discourse the illusion of being "God-given, natural, benign, inevitable" (van Dijk, 1997, p. 25) dominant discourses suppress multiple ways of seeing and champion their discourse as "natural" (Fairclough, 1989, p. 91). The consequence of naturalization is that once naturalized, the dominant discourse is emptied from its ideological content and its origins are disguised. When they are not seen as ideological but as natural, these discourses are not challenged and they are used to justify the subordination and devaluation of certain groups (for instance racism, sexism, classism) (Nibert, 2002, p. 13).

As a dominant and oppressive ideology, speciesism can be defined as the "unjustified disadvantageous consideration of treatment of those who are not classified as belonging to one or more species" (Horta, 2010, p. 244), and it has close links to anthropocentrism, the ideology of human supremacy (Weitzenfeld and Joy, 2014, p. 3). Speciesist discourses, thus, reflect this constructed superiority of humans blocking alternative ways of seeing animals. Dominant discourses also make sure that the domination of humans which govern animals' birth, death, and everything in between is normalized. The consent and legitimation of this domination come from a large group of people who demands and pays for the oppression of animals (Stibbe, 2001, p. 147) - for the dead bodies on their plates, for the joy of seeing wild animals in cages, and the like. Revealing the naturalizing aspect of the discourse may unveil the hidden ideological structures behind and make a case against speciesism.

Ideologies, including oppressive ones, take root in society through social institutions via multiple channels. Media is among the most potent channels which foster a medium reflecting and imposing power relations. The influence of media on the construction of reality and manufacturing consent for dominant ideologies has been widely studied (Herman and Chomsky, 1988; Hartmann \& Husband, 1974; Hardy, 2014; Albornoz, 2015) and the role of language in media portrayals forms an important part of it (Fowler, 1979, 1991; Hall et al., 1980; Fairclough, 1995; van Dijk, 1991).

Animals are increasingly included in media studies and scrutinized for unequal power relations. Leading works especially on the subfield of political economy of communication are the edited volume of Critical Animal and Media Studies 
(Almiron et al., 2015) and Almiron's study (2017). Earlier studies include Molloy (2011) who discusses animals on popular media over a wide range of human-animal contacts. Sealey \& Oakley (2013) examine anthropocentric language use in a wildlife documentary. Investigating the construction of animals in agriculture by analyzing news discourse, Freeman (2009) concludes that farmed ${ }^{2}$ animals are commodified, their emotions are not recognized, and they are portrayed as having no inherent value. Mitchell (2006) examines the order of discourse "animal farming" and analyzes in detail the discourses of production, science, enslavement, and achievement working together for the domination and objectification of farm animals. Glenn (2004) also examines factory farm industry discourse and part of her analysis includes the "speaking animals" in advertisements who happily sell themselves and their secretions. These advertisements create a virtual reality far from the actual conditions of farm animals, which distracts the viewer from the ethically and environmentally disastrous practices of the industry. The focus of Khazaal \& Almiron (2016) is the portrayal of nonhuman animals used for food in the news, and they compare the discourses of The New York Times and El Pais, concluding that while the former tries to conceal the underlying speciesist ideology, the latter uses a crude speciesism built on fear-mongering.

Although there are prominent studies on the linguistic constructions of human-animal relationships at zoos (Milstein, 2009; 2013) media discourse on zoos, in particular, remains an understudied area. The portrayal of wild animal captivity echoes the above-mentioned studies in that the ideology of speciesism naturalizes the oppressive aspects of this industry. However, stories on zoos mostly appear to be entertaining rather than informing which may even act as advertisements of the zoos in question. This colorful, fun, and carefree coverage of captive animals awakens an academic curiosity as to how the speciesist underpinnings of zoos are disguised and alternative views are silenced.

\section{Methodology}

The analysis is based on research conducted on Hürriyet newspaper's online search with the query word "zoo(s)". The search is limited to the news published from April 2018 to April 2019, and news that specifically covers zoos in Turkey are selected. The search conducted gives 42 news in total, with 9043 words and 61.005 characters. Besides this main corpus, additional texts that deal with zoos, such as their duties and responsibilities, are also employed in limited cases. The study does not cover a multimodal analysis; only textual materials are used. Since the analysis is carried out in Turkish news, translations are provided by the author. News stories are given code numbers such as A1 (article 1) due to space restrictions. List of news stories can be provided upon request.

2 Freeman (2009, p. 4) prefers the term farmed animals over farm animals since the latter denotes an inherent fact while the former recognizes that farming is something forcefully done to these animals. 
The daily national newspaper Hürriyet owned by Demirören Media Group was selected for this research since it is the leading online newspaper most widely visited according to Alexa.com which shares hit rates of websites ("Top Sites, 2019; see also Yılmaz, 2017). A preliminary search was conducted on numerous websites of printed newspapers to look for meaningful differences in discursive practices based on political stance. No meaningful differences were found between various newspapers, perhaps due to the overarching speciesist ideology ${ }^{3}$. Therefore, the research is limited to Hürriyet.

News stories on zoos generally appear under the categories of current news, local news, and a fewer portion under economy news. In the first two rubrics, zoos make the news in cases of new births, inaugurations, visits from important political figures, and rarely in cases of animals escaping the zoos. Zoo news in the economy category features numbers of visitors as a way of demonstrating the revenue-raising aspect of zoos. Although these news stories are not categorized under the rubric of entertainment, they are actually better examples of soft news catering to human interest, entertainment, and emotion. With photographs of "happy" animals, they often serve as zoo publicity than sites of information. These are evident in Hürriyet's stories, and also in other newspapers preliminarily investigated.

A form of Critical Discourse Analysis is performed based on methods proposed by Fairclough (1989, 2003), Wodak (2001), van Dijk (2000), and van Leeuwen (2008) by focusing on lexical choices, grammatical structures and discursive strategies of capitalism, hospitality and conservation which produces and sustains unequal power relations between humans and animals making it impossible to question the captivity of wild animals.

Following the idea that media mostly conveys the status quo (Hall, 1982), the study will also look for alternative voices favoring animal liberation or lack thereof. Structured silences are important factors in CDA since they point out to the naturalization process that disguises the ideological basis of discursive practices.

\section{Analysis and Findings}

\section{Representation of Animals}

In this section, animals are accepted as social actors, and the following questions are to be answered for revealing how they are represented: How are animals named and referred to linguistically? What traits, characteristics, qualities, and features are attributed to them? (adapted from Wodak, 2001, p. 72-3).

3 As a highly prevalent ideology, speciesism is sustained collectively in the zoo stories. The journalists who author the story, their sources, as well as authoritative figures in the stories can be said to share a speciesist stance since alternative voices are hardly heard. 
Linguistic references used for zoo'd animals ${ }^{4}$ display a wide range of choices wavering between the continuum of animal agency and objectification. For the most part, nonhuman individuals kept in the zoo often get represented by common nouns. These nouns travel a scale of abstraction going from a relatively specific genre name such as "Bengal tiger" or "Asia Minor spiny mouse", to the more abstract "species", "animal", "being", and "population". Only two stories mention "individuals" (A13, A14). Stibbe $(2001,2012,2015)$ attaches great importance to these choices by linking them to the practice of "erasure". The analysis of erasure deals with instances of discourse in which certain participants are excluded, masked, or backgrounded (Stibbe, 2015). Following Baudrillard, Stibbe (2015, p. 149-150) shares different types of erasures: "(a) the void, where 'something important' is completely excluded from a text; (b) the mask where it is erased but replaced by a distorted version of itself, and (c) the trace where something is partially erased but still present". At the objectification pole of the continuum, zoo discourses exemplify the third case of erasure: "the trace". Animals are defined by their species names -such as bear- which excludes the possibility of painting a vivid picture of the complexity of actual bears having different personalities and unique characteristics. This, however, is the mildest form of erasure. When hypernyms replace species names - such as mammal or bird, animal, being, organism or even flora and fauna, representations grew more and more abstract being less likely to invoke vivid mental images (Stibbe, 2012, p. 4849). Moreover, using mass nouns rather than count nouns strips the individuality of animals, lumping them all together with the ideological supposition that each animal can be easily replaced within a category (Stibbe, 2001, p. 151). When the individuality of each animal is erased using the above mentioned lexical choices, people are less likely to empathize with and connect to the individual animals.

At the other end of the continuum is the curious and yet typical case of zoos: the practice of giving proper names to animals. A zebra family named Zafer, Gonca and Yağmur; Izmir, an elephant; Ege, a camel calf; Duman, a bear cub; Yaprak and Ceviz, two tamarin babies, and many other examples demonstrate the other pole of subjectivity. Personal names grant individuality, which in turn creates empathy (Dunayer, 2001, p. 141). Yet, the power rests in giving names to the animals, and this practice is generally done by the staff, and in some occasions, the city dwellers get the opportunity to name newborn animals, as is the case in Izmir. The practice of giving names to animals is not a universal tendency, though. Many zoos in America prefer giving animals numbers rather than Western names in an attempt to preserve the connotation of wilderness. If names are given, then, mostly African names such as Mshindi, Kweli, or Mia Moja are chosen, again to create the illusion of the distant wild lands (Braverman, 2013, p. 9). In any case, according to Dunayer $(2001$, p. 89) giving personal names is a public relation "ploy rather than an acknowledgement of nonhuman individuality".

4 I will use the term zoo'd animals as suggested by Milstein (2013), by making it clear that putting animals in zoos is an "active process in which humans are the implicit agents" (p. 179). 
Other references used for animals that take on meaning in broader discursive themes are "guests", "family" referring to the Natural Park as a whole, and "members". Calling someone a guest points to common social scripts and it establishes a relationship between host and the guest. First of all, especially in our country, guests are greatly valued. Hosts generally do their best to serve the guest(s), make them feel worthy and comfortable. Based on this hospitality theme, which will be dealt with in detail later on, the zoo discourse constructs a welcoming space for the animals with the zoo staff pouring their utmost care for them. However, the script falls apart when one realizes the fact that a guest might leave anytime, yet animals are bound to spend their lives in captivity. The use of "members" similarly depicts the script of a club, where members can enjoy multiple benefits. Lastly, constructing the zoo as a "family" illustrates a loving and caring atmosphere. These representations cooperate with other strategies to depict a benign image of zoos.

Adjectives are reflections of the characteristics and features we attribute to social actors. Negative or positive labels are generally used to determine the ideological stance of the author and thus contribute to the construction of subjects. For instance, women are generally described through their looks, youth, sexuality, and desirability for men (Goatly, 2000, p. 56) which puts discursive constraints on the expected roles of women. Similarly, animals in zoo news are generally characterized by their status such as endangered, rare, by their physical needs and attributes such as vulnerable to cold, who prefer warmth, active, cold-blooded, those that are exhausted from heat, but mostly through their visual qualities. Among these visual qualities are the colors of animals: white lion, black leopard, black swan, colorful animals, their appearance largest, majestic, beautiful, healthy, attention grabber. Yet an overworded quality is their cuteness: cute babies, cute friends, mascots, little members. Especially newborn animals make into headlines multiple times and are described as sevimli (Eng. cute, lovely, adorable). A notable underwording can be distinguished around the social qualities of animals. Except for a few cases where family relations of animals are shared, animals are rarely mentioned by their emotions, idiosyncratic characteristics or reactions. Thus, animals are presented mostly through the roles they play, namely the receiving end of human gaze.

Besides lexical choices, grammatical structures play an essential role in the representation of reality. Clause grammar provides models for construing the world of experience through different processes, known as transitivity (Halliday, 2004 , p. 170). Among several processes such as material, relational, and mental which emphasize inner or outer experiences, mental processes stand out in zoo discourses. This is in stark contrast with farming discourses in which material processes are intensely preferred and animals are constructed as affected participants, passive ends ${ }^{5}$ (see for instance Mitchell, 2006; Ergin Zengin, 2017). In

5 Zoo'd animals are also constructed as affected participants in material processes in high numbers, yet animals in oppressive industries are hardly ever portrayed as conscious beings, which makes this case interesting. 
mental processes, zoo'd animals are not doers, yet they are conscious subjects who have inner experiences like emotion, perception, and thought. Sentences such as "animals enjoyed the snow" (A1), "they haven't neglected to roam around" (A1), "they adopted the park" (A6), "to enjoy the sunshine" (A13) and many more construe a mental experience not different than that of humans. Similar to the practice of giving proper names, these choices echo sentient beings and individuals. Nevertheless, although they are granted agency, animals are portrayed only in ways exciting and fun to humans. They never sulk, cry in pain, get bored, etc. They are subjects so far as they prove worthy of human gaze and be instrumental in providing joy to humans.

\section{Capitalist Discourse}

Capitalism is characterized by total control over the production processes, high capacity production, automation, mechanization, and rationalization (Noske, 1997, p. 11). Thus, discourses of capitalism include " a narrative of progress" offering "unprecedented opportunities for "growth" through intensified "competition"' (Fairclough, 2000, p. 148). Many scholars point out that capitalist production is linked to animal oppression (see Torres, 2007; Noske, 1997; Nibert, 2002).

A familiar prospect of capitalist discourse is to see animals as commodities that are to be bought and sold. With the requirements of the market in the forefront, animals are treated as merchandise to be introduced to the market. Animals could also be portrayed as service providers in the education sector, for instance. In this regard, animals bear a value that cannot be separated from the capital that they deliver to the organization or service that they provide.

From the following examples, we can infer that animals are considered as raw materials used in "production." Animals seem like a product launch, within a project (line 9), of a season (line 8), going through the phases of demand (line 10,12), purchase/buying (line 11,17), production (line 3,4,6), and lastly distribution (line 7). Also, some Turkish verbs clearly evoke the discourse of business, which gets lost in translation. For example, line 2 uses the Turkish verb kazandırmak, literally "make them win", creating the connotation that animals are a valuable asset to the company/institution. Line 13, makes use of the verb bünyesine dahil etmek, (to incorporate), which is generally used in a prideful manner when a successful employee signs a deal with the related company. In these sentences, animals are thus employees of a company, rather than raw materials.

Another recurrent theme in capitalist discourse is the notion of efficiency. Similar to the inhumane working conditions of workers incessantly expected of higher efficiency rates, animals are to outperform themselves in various fields ${ }^{6}$. Zoo discourses reveal that high rates of birth are a positive trait and highly en-

6 For instance animals in agribusiness animals are treated as machines that must "produce" more milk, more meat, more eggs (see Singer, 2009; Sayers, 2014) 
couraged. Sentences such as "obtaining six offspring from the coatis" (line 15) or "continually getting offspring" (line 16) clearly disregard birth as a natural process and construe animals as highly efficient machines. To "obtain" and to "get" offspring conjure up a product, rather than a living being, which is made after a manufacturing process.

Table 1. Capitalist Discourse

\begin{tabular}{ll}
$\mathbf{1}$ & ...to introduce different animal species after obtaining them (E1) \\
\hline $\mathbf{2}$ & Bring endangered animals to the zoo... (E1) \\
\hline $\mathbf{3}$ & ...to put into service some of the animal species for breeding by producing them. (E1) \\
\hline $\mathbf{4}$ & $\begin{array}{l}\text { By producing large amounts of game animals whose numbers decline day by day in nature } \\
\text { (E1) }\end{array}$ \\
\hline $\mathbf{6}$ & ...transforming crossbreed animals into highly efficient races (E1) \\
\hline $\mathbf{7}$ & We try to produce them as much as we can and we try to introduce this mouse to people. \\
\hline $\mathbf{8}$ & Turkey. (A3) \\
\hline $\mathbf{9}$ & We have opened the winter season at Gaziantep Zoo. (A5) \\
\hline $\mathbf{1 0}$ & In the surveys, giraffes, elephants and zebras were asked for by our visitors. (A6) \\
\hline $\mathbf{1 1}$ & Among these animals, we have bought (our) zebras for this year (A6) \\
\hline $\mathbf{1 2}$ & $\begin{array}{l}\text { Citizen's demand is also substantial. They want to see new species and our work will } \\
\text { continue in this direction. (A6) }\end{array}$ \\
\hline $\mathbf{1 3}$ & In 2019, giraffes and elephants will be included in the Tarsus Animal Park. (A6) \\
\hline $\mathbf{1 4}$ & ...the cat species... were brought with their CITIES documents. (A7) \\
\hline $\mathbf{1 5}$ & ...Arsun who shares that they have obtained 6 offspring from the coatis...(A19) \\
\hline $\mathbf{1 6}$ & Our gazelles also have a good population; we can continually get offspring. (A41) \\
\hline $\mathbf{1 7}$ & ...number of animals and species diversity increases with purchases from abroad (A9)
\end{tabular}

As previously mentioned, competition is an inextricable factor of capitalism. Stories feature animals as if they are willing participants of this competition. In the following quotations, the animals are portrayed as if they are about to participate in a race. They display their abilities and performances to the visitors- the spectators of the competition. This aggressive stance sometimes gets transferred to the children who find themselves competing with each other to see the animals. 
Table 2. Competition Discourse

1 Our zebras named "Zafer, Gonca and Yağmur" took place in our park as the 81st species (A6).

\begin{tabular}{ll}
\hline $\mathbf{2}$ & ...now the rhinos have taken their place at Bursa Zoo. (A28) \\
\hline $\mathbf{3}$ & $\begin{array}{l}\text { It is reported that the new species placed in their homes in Izmir will meet with the } \\
\text { visitors after the adaptation process. (A14) }\end{array}$ \\
\hline $\mathbf{4}$ & $\begin{array}{l}\text { In addition to their fast running abilities, these interesting animals can show excellent } \\
\text { swimming performance in the water. (A14) }\end{array}$ \\
\hline $\mathbf{5}$ & $\begin{array}{l}\text {...children almost competed with each other to see animals such as giraffes, elephants, } \\
\text { lions, tigers, bears, ostriches, zebra, and flamingos. (A37) }\end{array}$
\end{tabular}

As seen, animals are integrated into the language of capitalism as raw materials, employees, finished products, or just numbers required to measure development. They are clearly commodified, objectified and denied a subject-status.

\section{Hospitality Discourse}

On a growing basis, modern zoos depict themselves as institutions moving away from domination and control toward a new position of care and stewardship (Braverman, 2013, p. 5). This new stance goes hand in hand with the discourse of conservation: in order to protect someone, providing care is in order. The metaphor of host/guest plays an integral part in leading potential visitors to believe in the benevolence of the zoo. Resting on the connotations of the wild as brutal, chaotic, ferocious, animals severed from their natural habitats are deemed lucky.

The discourse of hospitality must without a doubt be taken into consideration in its socio-cultural context since Turkish culture is renowned for its hospitality. Guests are always welcome and treated with special care. This hospitality culture and discourse find its way to define the space of zoo and relationships within, which, in fact, mostly run through profits and economic interest. In the discourse of hospitality employed by the media, the visitors (clients) are evidently portrayed as guests welcomed by the zoo, with an increasing number. A more interesting case is to represent animals as guests of the zoo and to depict the zoo as a place which hosts/welcomes animals from all around the world, as a safe haven. As they are designated as guests (in Turkish with two synonyms: misafir and konuk), it is assumed that animals are free to leave whenever they like, which is far from the truth. Line 4, shows that Muhteşem, a crocodile, is a "guest" of the zoo for 13 years, a very long duration for a guest, indeed. In several cases, animals are promoted from being a guest to being the residents of the zoo (line 6). Many articles also announce animals as members (line 7), which creates an illusion that they belong to a special group with privileged rights. 
Table 3. Hospitality Discourse

1 Sincan Zoo, which welcomes/receives thousands of animal lovers from the country and from abroad... (E2)

\begin{tabular}{ll}
\hline $\mathbf{2}$ & ...Bursa Zoo hosts/ is home to 121 species and almost 1,200 animals (A1) \\
\hline $\mathbf{3}$ & ...the new guests of Tarsus Animal Park receive significant attention from the visitors (A6) \\
\hline $\mathbf{4}$ & ...said that they were pleased to have Muhteşem as a guest for 13 years (A21) \\
\hline $\mathbf{5}$ & Rhinos, new guests of Bursa Zoo (A28) \\
\hline $\mathbf{6}$ & $\begin{array}{l}\text { Among the new residents of the İmir Natural Life Park, capybaras... are to be counted as } \\
\text { well (A14) }\end{array}$ \\
\hline $\mathbf{7}$ & $\begin{array}{l}\text { In the Zoo, which have increased its numbers (of animals) with its new members brought } \\
\text { from other zoos... (A19) }\end{array}$
\end{tabular}

Congruent with the hospitality discourse, is the discourse of care. As a guest would experience, animals are taken care of with utmost diligence. They have special rooms with underfloor heating and air-conditioning (line 3). They live a comfortable life (line 7), getting a 5-star hotel treatment (line 4). The news evokes images of families settling into a life of luxury and comfort with everything they need ready at their feet. As a sign of luxury, animals are also hand-fed by the mayor (line 5). These discourses call to mind the term "hotelification" coined by Lee (2005, p. 47). As hotels provide accommodation and food, hotelification refers to the incorporation of wild animals within these facilities (47). Nevertheless, the discourses of Turkish zoos enhance the hotelification discourse by adding connotations of hospitality: care, respect, love, and offerings.

Table 4. Care Discourse

\begin{tabular}{ll}
$\mathbf{1}$ & $\ldots 46$ hatchlings that have recently hatched are looked after with care (A3) \\
\hline $\mathbf{2}$ & $\begin{array}{l}\text {...iguanas meet their visitors in special rooms, the temperature of which do not fall below } \\
\text { 30 degrees (A3) }\end{array}$ \\
\hline $\mathbf{3}$ & $\begin{array}{l}\text { Special Section (A3), with underfloor heating and air-conditioning (A4), technological } \\
\text { infrastructure (A5) }\end{array}$ \\
\hline $\mathbf{4}$ & Animals get the comfort of a 5-star hotel (A5) \\
\hline $\mathbf{5}$ & $\begin{array}{l}\text { Mayor Aktaş, who visited the shelters and fed the lemurs and giraffes with his hands... } \\
\text { (A28) }\end{array}$ \\
\hline $\mathbf{6}$ & $\begin{array}{l}\text {...veterinarians and staff at the zoo, provide the attention needed to the charming guests } \\
\text { of the zoo. (A34) }\end{array}$ \\
\hline $\mathbf{7}$ & $\begin{array}{l}\text { The zoo attracts attention with its natural habitat and the comfortable life that it provides } \\
\text { to animals (A19) }\end{array}$ \\
\hline $\mathbf{8}$ & $\begin{array}{l}\text {...The zebra family living in the } 18 \text { thousand square meters of African Savanna section... } \\
\text { (A20) }\end{array}$ \\
\hline $\mathbf{9}$ & African dwarf hedgehog settled in Sincan (A25)
\end{tabular}


This discourse falls apart when probed a little. Wild animals in zoos are not guests; they are prisoners, inmates, captives as suggested by Dunayer (2001, p. 192). Animals are dislocated from their natural habitats and exhibited in enclosures which may or may not be in the form of cages. A study on the comparison of enclosure sizes and natural home ranges demonstrate that megafauna in zoos such as elephants, giraffes, lions, and bears live in enclosures 1000 times smaller in average than their minimum home range, whereas areas that zoo mammals live are 100 times smaller than their home ranges. When applied to humans, this parallels to living in a telephone box for a lifetime (Casamitjana, 2003, p. 13). Hence, increasingly used terms such as natural parks, habitats, and conservation parks when referring to zoos are nothing but euphemisms aiming to cover the ugly truth of captivity?. Moreover, under captivity, "natural modes of choice and appropriation of foods are suspended and replaced by 'room service' foods" (Lee, 2005, p. 50) which differ fundamentally from their natural diets in wild (p. 49).

Apart from space and food regulations, a hugely ignored factor is related to natural climatic conditions. The majority of animals are transported from tropical or arctic climates and located mostly in temperate climates of the developed world (Lee, 2005, p. 31). Even with the best intentions, animals that typically live outside temperate climates such as polar bears cannot thrive. Apart from this highly significant fact, Dunayer (2001, p. 76) provides multiple news of animal's death: due to dying from cold, rape, assault, lack of medical attention, and even starvation since many animals refuse to eat due to the shock of capturing, dislocating, and relocating. Zoos are in no way guesthouses.

This hospitality discourse is breached in only one story in which visitor's thoughts are interrogated after a wolf runs away from the zoo. Kadir Tekdemir, a visitor, simply tells "I am happy in a way that she ${ }^{8}$ got away. She found her freedom. There is no need to imprison them" (A24). This view can be seen as a minimal puncture in the structured silence and erasure surrounding zoo discourses. Apart from this comment in an otherwise speciesist news story, no other alternative voices are heard.

\section{Conservation Discourse}

Another track of discourse pursues the virtues of protection and conservation. The beneficiaries of this discourse are wild and endangered animals that are dying off and facing the threat of going extinct, as well as injured wild animals. Zoos, at this point, claim to provide shelter to the animals whose numbers "decline day by day in nature" (line 7), "decreased in their natural habitats" (line 1), and "who are "going extinct" (line 4). This rationale overlooks the reason why,

7 Repetetive behaviour such as pacing, over-grooming, self-mutilation, chewing cage bars clearly show stress, anxiety, and/or depression (Lamont, 2019).

8 Turkish language does not distinguish gender or inanimity/animity in third person singular. I personally chose to translate as "she" since the visitor grants agency to animals. 
in the first place, the animals are going extinct, and why their numbers are decreasing in their habitats. The workings of doublespeak are apparent, here. For instance, when the zoo boasts on "producing large amounts of game animals whose numbers decline day by day in nature" (line 7), the human actors who are responsible for their death are erased. "Game animals", a human-made category to classify wild animals to be killed, are "produced" in order to be released to nature -and then to be killed again. Very recently, the Ministry of Agriculture and Forestry have lodged a tender for two red deer who are "produced" in conservation centers, to be killed for "game tourism". 14.000 Turkish Liras were to be gained for each killed animal but due to public reactions the tender was canceled ("Tarım ve Orman Bakanlığı'ndan", 2019; "Tarım ve Orman Bakanlığı'nın, 2019).

Treating wild animals and acting as an "animal rehabilitation center" are also listed among the responsibilities of a zoo. Injured animals are "treated" and "brought back to life" (line 5). Yet, the causes of their injury or sickness are never shared, except one case: "incorrect hunting" (line 8). This noun phrase depicts a worldview where hunting is normal but must be done correctly.

Table 5. Conservation Discourse

1 Sevim, stating that the number of these mice have decreased in their natural habitats... (A2)

\begin{tabular}{ll}
\hline $\mathbf{2}$ & $\begin{array}{l}\text { Park staff who has treated hundreds of animals such as... and released them to nature, } \\
\text { brought injured animals back to life many times (A9) }\end{array}$ \\
\hline $\mathbf{3}$ & Uzuntarla Natural Park Ormanya will contribute to the animal population (A15) \\
\hline $\mathbf{4}$ & $\begin{array}{l}\text { These animals will reproduce even more because there are animals that are going extinct } \\
\text { (A15) }\end{array}$ \\
\hline $\mathbf{5}$ & $\begin{array}{l}\text { Deer, wolves and other animals that have been hurt in nature are brought to the zoo, } \\
\text { treated, and then released back to nature (A17) }\end{array}$ \\
\hline $\mathbf{6}$ & $\begin{array}{l}\text { To bring endangered animals to the zoo, to enable their treatment, protection and their } \\
\text { reproduction for securing their lineages... (E1) }\end{array}$ \\
\hline $\mathbf{7}$ & $\begin{array}{l}\text { Releasing animals to nature by producing large amounts of game animals whose numbers } \\
\text { decline day by day in nature (E1) }\end{array}$ \\
\hline $\mathbf{8}$ & $\begin{array}{l}\text { To ensure that wild animals that are injured due to incorrect hunting and that are sick are } \\
\text { released to their habitat after receiving treatment (E1) }\end{array}$
\end{tabular}

This conservation discourse is further reinforced with a claim of close affinity to natural habitats. The "special" areas where animals are kept are likened to "their natural habitats" (line 1). Talking about the Natural Park, built in Kocaeli, the Mayor states that "the animals are not trapped in certain areas, they are in nature" (line 2). This sentence might serve as a confession, admitting that limiting the space of animals is not humane, after all. Another illusion-breaking extract tells us that lions cubs will "adapt to their natural living environments" (line 3). No animal would have the need to adapt to their surroundings in their actual habitats. Moreover, the aspiration over the construction of natural habitats is more 
about humans than animals, who don't want to be reminded about the captivity of animals and feel bad about it (cited in Milstein, 2013, p. 165).

While a prominent amount of news represents zoos as the most advantageous place for animals, some slips occur. A story featuring new species who are brought to the zoo informs us that shelter conditions are improved so that new members can "live in more favorable conditions" (line 4), which presupposes that animals at the zoo lived in worse conditions. Another story talks about the approaching religious holiday and the preparations done at the zoo, one of which is cleaning the shelter (line 5). Again, the presupposition is that the shelter is not cleaned regularly except for special occasions.

Aside from animal welfare, animal rights are barely touched upon in the news. From the 42 stories, only one article mentions animal rights linked to zoos. However, the story is quite unexpected since it features the Grand National Assembly of Turkey, which aims at "drawing attention to animal rights" (line 6) by building a mini zoo.

Table 6. Habitat Discourse

1 ...the animals are kept alive in special sections as if they are in their natural habitats (A17)

2 Here, the animals are not trapped in certain areas, they are in nature. People are very glad about this (A15)

33 lion cubs also live their lives as they adapt to their natural living environments (A34)

4 Shelter conditions were also improved in order for the new members of the zoo to live in more favorable conditions (A25)

$5 \quad$ As in every holiday, we have completed our preparations for this holiday and cleaned our shelters (A32)

6 In the campus of Grand National Assembly of Turkey, it is planned to build a mini zoo for drawing attention to animal rights $(\mathrm{A} 26)$

Before my concluding remarks, extra words for the conservation discourse is in order. Modern zoos bring forward conservation, and education among their primary missions (Braverman, 2013, p. 5; see also Patrick et al., 2007). However, Francione $(2000$, p. 24) argues that these breeding programs select only a trivial portion among the species held in captivity ${ }^{9}$, and among these species, the rate of successfully released animals is quite low. This may be due to the fact that animals lose their wildness once they are brought into captivity. Lee (2005, p. 24-25) discusses the ontological status of zoo'd animals and argues that the term "wild animals in captivity" is an oxymoron since being wild means being outside human design, control, and manipulation. Then, zoo'd animals who get

9 For instance, for the five big zoos in Turkey studied by Altuğ Turan and Malkoç True (2017), even the percentage of species that are in conservation are quite low: virtually absent in two zoos, the remaining three are $5 \%, 10 \%$ and $55 \%$. 
used to the human presence becomes tamer in the process of breeding and loses their flight reaction (Lee, 2005, p. 27) which makes them vulnerable in their own habitats. This makes conservation programs, if they are by any chance put into practice, illogical and unsustainable. Moreover, as mentioned above, the existence of endangered animals is the very problem that must be dealt with and zoo critics argue that zoos are unable to tackle the primary causes of global biodiversity loss (Margodt, 2010; Jamieson, 2006). Under these circumstances, the obvious solution to 'saving' wild animals is protecting their habitats and sanctuaries (Kemmerer, 2010, p. 42).

\section{Conclusion}

This study has demonstrated that zoos are speciesist institutions of power and dominance exerted by humans to animals through practices of captivity, gaze, and objectification. Through language, these practices are camouflaged and arguments in favor of the zoos' existence such as conservation, education, and the least moral of them, recreation are vastly foregrounded. As discussed above, these arguments don't hold up, and the raison d'etre of zoos are, thus, never animals themselves.

News discourses are known for promoting dominant ideologies. This naturalized and unchallenged ideologies are viable for critical discourse analysis which aims at denaturalizing and exposing latent ideologies. The analysis shows that zoo'd animals have instrumental value as is quite apparent in the use of capitalist discourse. However, the objectification of animals is camouflaged through euphemisms, use of personal names, mental processes and also through discursive strategies of hospitality and conservation. News stories paint a rosy picture with cute babies, joyful animals, and visitors enjoying their lives, yet they are misleading and one-sided, with only one story conveying the alternative view of a visitor.

These discursive choices block the way of resistance and change since the first step of resistance is to realize that the status quo is unjust. Resistance is only possible when we accept "the seemingly simple, but profoundly radical, premise that nonhuman animals are subjects with agency, not objects to be used as humans see fit" (Nocella II, 2014, p. xix). If we, humans, are genuine in our desire to protect wild animals, this protective intervention does not need entrance fees, cages, bars, designs to make animals visible or unnatural surroundings. We need sanctuaries, establishments that critical animal scholars propose such as nooz (Kemmerer, 2010). Zoos have outlived their place in our society. 


\section{References}

Acampora, R. R. (Ed.). (2010). Metamorphoses of the Zoo: Animal Encounter After Noah. Lanham, Md: Lexington Books.

Albornoz, L. A. (Ed.), Barnett, I. (Trans.). (2015). Power, Media, Culture: A Critical View from the Political Economy of Communication. Houndmills, New York: Palgrave Macmillan.

Almiron, N., Cole, M., \& Freeman, C. P. (Eds.). (2015). Critical Animal and Media Studies: Communication for Nonhuman Animal Advocacy. New York: Routledge.

Almiron, N. (2017). Beyond Anthropocentrism: Critical Animal Studies and the Political Economy of Communication. The Political Economy of Communication, 4(2). Retrieved from http://www.polecom.org/index.php/polecom/article/view/71

Altuğ Turan, i., \& Malkoç True, E. (2017). Kentsel Bir Dış Mekân Olarak Hayvanat Bahçeleri: Türkiye'den Öne Çıkan Örnekler. Adnan Menderes Üniversitesi Ziraat Fakültesi Dergisi, 14(2), 23-28.

Anderson, K. (1998). Animal Domestication in Geographic Perspective. Society and Animals, 6(2), 119-135.

Andersson Cederholm, E., Björck, A., Jennbert, K., \& Lönngren, A. S. (2014). Exploring the animal turn: human-animal relations in science, society and culture. Lund: Pufendorfinstitutet.

Association of Zoos \& Aquariums. (n.d.). Homepage. Retrieved June 2, 2019, from https://www.aza.org/

Best, S. (n.d.). Zoos and the End of Nature. Retrieved June 3, 2019, from http:// www.drstevebest.org/ZoosAndTheEnd.htm

Best, S., J Nocella, A., Kahn, R., Gigliotti, C., \& Kemmerer, L. (2007). Introducing Critical Animal Studies. Journal for Critical Animal Studies, 5.

Bostock, S. S. C. (2003). Zoos and Animal Rights: The Ethics of Keeping Animals. London; New York: Routledge.

Braverman, I. (2013). Zooland: The Institution of Captivity. Retrieved from http://web.a.ebscohost.com/ehost/ebookviewer/ebook? sid=e634ba3e-b081-4c49-9758-a87b375750c1\%40sessionmgr4007\&vid=0\&format=EK

Bryant, C. D. (1979). The Zoological Connection: Animal-Related Human Behavior. Social Forces, 58(2), 399.

Casamitjana, J. (2003). Enclosure Size in Captive Wild Mammals: A Comparison Between Uk Zoological Collections and the Wild. Retrieved from: https:// www.researchgate.net/publication/265044781_ENCLOSURE_SIZE_IN_CAP_ TIVE_WILD_MAMMALS_A_comparison_between_UK_zoological_collections_ and_the_wild 
DeMello, M. (2012). Animals and Society: An Introduction to Human-Animal Studies. New York: Columbia University Press.

Dunayer, J. (2001). Animal Equality: Language and Liberation. Derwood: Lantern Books.

Ergin Zengin, S. (2017). İnsan-Hayvan İlişkisinin Söyleme Yansıması: Bir Agrosanayi Örneği. Edebiyat Fakültesi Dergisi, 34 (2), 61- 81.

European Association of Zoos and Aquaria. (n.d.). Homepage. Retrieved June 7, 2019, from https://www.eaza.net/j

Fairclough, N. (1989). Language and Power. New York: Longman.

Fairclough, N. (1995). Media discourse. London: Arnold.

Fairclough, N. (2000). Language and Neo-Liberalism. Discourse \& Society, 11(2), 147-148.

Fairclough, N. (2003). Analysing Discourse: Textual Analysis for Social Research. Retrieved from http://www.dawsonera.com/depp/reader/protected/external/ AbstractView/S9780203697078

Fowler, R., Hodge, B., Kress, G., \& Trew, T. (1979). Language and Control. Routledge \& K. Paul.

Fowler, R. (1991). Language in the News: Discourse and Ideology in the Press. London; New York: Routledge.

Francione, G. L. (2000). Introduction to Animal Rights: Your Child or the Dog? Philadelphia: Temple University Press.

Freeman, C. P. (2009). This Little Piggy Went to Press: The American News Media's Construction of Animals in Agriculture. The Communication Review, 12(1), 78-103.

Glenn, C. B. (2004). Constructing Consumables and Consent: A Critical Analysis of Factory Farm Industry Discourse. Journal of Communication Inquiry, 28(1), 63-81.

Goatly, A. (2000). Critical Reading and Writing: An Introductory Coursebook. London; New York: Routledge.

Gruen, L. (2018). Incarceration, Liberty, and Dignity. In A. Linzey \& C. Linzey (Eds.), The Palgrave Handbook of Practical Animal Ethics (pp. 153-163). London: Palgrave Macmillan.

Günergun, F. (2006). Türkiye'de Hayvanat Bahçeleri Tarihine Giriş. In A. Özen (Ed.), I. Ulusal Veteriner Hekimliği Tarihi ve Mesleki Etik Sempozyumu Bildirileri (pp. 185-218).

Hall, S., Hobson, D., Lowe, A., \& Willis, P. (Eds.). (1980). Culture, Media, Language Working Papers in Cultural Studies, 1972-79. London; New York: Routledge. 
Hall, S. (1982). The Rediscovery of "Ideology": Return of the Repressed in Media Studies. In T. Bennett, J. Curran, M. Gurevitch, \& J. Wollacott (Eds.), Culture, Society and the Media (pp. 52-86). Retrieved from http://qut.eblib.com.au/patron/ FullRecord.aspx?p=242285

Halliday, M. A. K., \& Matthiessen, C. M. I. M. (2004). An Introduction to Functional Grammar (3 edition). London; New York: Hodder Education Publishers.

Hallman, B. C., \& Benbow, M. (2006). Canadian Human Landscape Examples: Naturally cultural: the zoo as cultural landscape. The Canadian Geographer/Le Geographe Canadien, 50(2), 256-264.

Hardy, J. (2014). Critical Political Economy of the Media: An Introduction. London; New York: Routledge.

Hartmann, P. G., \& Husband, C. (1974). Racism and the Mass Media: A Study of the Role of the Mass Media in the Formation of White Beliefs and Attitudes in Britain. London: Davis-Poynter.

Herman, E. S., \& Chomsky, N. (1988). Manufacturing Consent: The Political Economy of the Mass Media. New York: Pantheon Books.

Hodge, R. I. V., \& Kress, G. R. (1993). Language as Ideology (2nd ed.). London; New York: Routledge.

Horta, O. (2010). What is Speciesism. J Agric Environ Ethics, 23, 243-266.

Jamieson, D. (2006). Against Zoos. In P. Singer (Ed.), In Defense of Animals: The Second Wave (pp. 132-143). Malden, MA: Blackwell Pub.

Kemmerer, L. (2010). Nooz: Ending Zoo Exploitation. In R. R. Acampora (Ed.), Metamorphoses of the Zoo: Animal Encounter After Noah (pp. 37-56). Lanham: Lexington Books.

Khazaal, N., \& Almiron, N. (2016). "An Angry Cow Is Not a Good Eating Experience": How Us and Spanish Media Are Shifting from Crude to Camouflaged Speciesism in Concealing Nonhuman Perspectives. Journalism Studies, 17(3), 374-391.

Kruse, C. R. (2002). Social animals: Animal studies and sociology. Society and Animals, 10(4), 375-380.

Lamont, D. (2019, April 12). Beyond the Zoo: How Captivity Affects the Mental Well-Being of All Animals. Retrieved June 13, 2019, from One Green Planet website: https://www.onegreenplanet.org/animalsandnature/how-captivity-effects-the-mental-well-being-of-all-animals

Lee, K. (2005). Zoos: A Philosophical Tour. Basingstoke; New York: Palgrave Macmillan.

Malamud, R. (1998). Reading Zoos: Representations of Animals and Captivity. Basingstoke: Macmillan Press. 
Margodt, K. (2010). Zoos as Welfare Arks? Reflections on an Ethical Course for Zoos. In R. R. Acampora (Ed.), Metamorphoses of the Zoo: Animal Encounter After Noah (pp. 11-36). Lanham: Lexington Books.

Mayr, A. (2008). Language and Power: An Introduction to Institutional Discourse. London; New York: Continuum.

Milstein, T. (2009). "Somethin' Tells Me It's All Happening at the Zoo": Discourse, Power, and Conservationism1. Environmental Communication, 3(1), 25-48.

Milstein, T. (2013). Banging on the Divide: Cultural Reflection and Refraction at the Zoo. In E. Plec (Ed.), Perspectives on Human-animal Communication: Internatural Communication (pp. 162-181). New York; London: Routledge.

Mitchell, L. (2006). Animals and the Discourse of Farming in Southern Africa. Society \& Animals, 14(1), 39-59.

Molloy, C. (2011). Popular Media and Animals. Basingstoke ; New York: Palgrave Macmillan.

Montford, K. S. (2016). Dehumanized Denizens, Displayed Animals: Prison Tourism and the Discourse of the Zoo. PhiloSOPHIA, 6(1), 73-91.

Morin, K. M. (2015). Wildspace: The cage, the supermax, and the zoo. In R.-C. Collard \& K. Gillespie (Eds.), Critical Animal Geographies: Politics, intersections, and hierarchies in a multispecies world (pp. 73-91). Abingdon, Oxon; New York: Routledge.

Mullan, B., \& Marvin, G. (1987). Zoo Culture. Urbana, Chicago: University of Illinois Press.

Myers, O. E. (2003). No Longer the Lonely Species: A Post Mead Perspective on Animals and Sociology. International Journal of Sociology and Social Policy, 23(3), 46-68.

Nibert, D. (2002). Animal Rights/Human Rights: Entanglements of Oppression and Liberation. Lanham: Rowman \& Littlefield Publishers.

Nocella II, A. J., Sorenson, J., Socha, K., \& Matsuoka, A. (Eds.). (2013). Defining Critical Animal Studies: An Intersectional Social Justice Approach for Liberation. New York: Peter Lang Inc.

Noske, B. (1997). Beyond Boundaries. Montreal, New York, London: Black Rose Books.

Özen, A. S. (2016). Türkiye'de B Grubu Hayvanat Bahçeleri ve Akvaryumların Durumu. Dumlupınar Üniversitesi Fen Bilimleri Enstitüsü Dergisi, 36, 8.

Patrick, P. G., \& Tunnicliffe, S. D. (2013). Zoo Talk. Dordrecht; New York: Springer.

Regan, T. (2004). The Case for Animal Rights (Updated ed.). Berkeley: University of California Press. 
Ritvo, H. (1990). The Animal Estate: The English and Other Creatures in the Victorian Age. London: Penguin.

Sayers, D. O. (2014). The Most Wretched of Beings in the Cage of Capitalism. International Journal of Historical Archaeology, 18(3), 529-554.

Sealey, A., \& Oakley, L. (2013). Anthropomorphic Grammar? Some Linguistic Patterns in the Wildlife Documentary Series Life. Text \& Talk, 33(3).

Singer, P. (2009). Animal Liberation: The Definitive Classic of the Animal Movement. New York: Harper Perennial Modern Classics.

Smart, A. (2014). Critical Perspectives on Multispecies Ethnography. Critique of Anthropology, 34(1), 3-7.

Stibbe, A. (2001). Language, power and the social construction of animals. Society \& Animals, 9(2), 145-161.

Stibbe, A. (2006). Deep Ecology and Language: The Curtailed Journey of the Atlantic Salmon. Society \& Animals, 14(1), 61-77.

Stibbe, A. (2012). Today We Live Without Them: The Erasure of Animals and Plants in the Language of Ecosystem Assessment. ECOS, 33(1), 47-53.

Stibbe, A. (2015). Ecolinguistics: Language, Ecology and the Stories We Live By. London; New York: Routledge, Taylor \& Francis Group.

Tarım ve Orman Bakanlığı'ndan geyik ihalesi: Vurulmak için açık artırmayla satışa çıkartıldı. (2019, May 27). Retrieved June 5, 2019, from http://www.cumhuriyet. com.tr/haber/turkiye/1412277/Tarim_ve_Orman_Bakanligi_ndan_geyik_ihalesi_ Vurulmak_icin_acik_artirmayla_satisa_cikartildi.html

Tarım ve Orman Bakanlığı'nın 'geyik ihalesi'ne mahkeme "dur" dedi. (2019, May 31). Retrieved June 5, 2019, from http://www.cumhuriyet.com.tr/haber/turkiye/1420432/Tarim_ve_Orman_Bakanligi_nin__geyik_ihalesi_ne_mahkeme_. dur_dedi.html

Taylor, N. (2012). Humans, Animals, and Society: An Introduction to Human-Animal Studies. New York: Lantern Books.

This zoo is 'hell on Earth.' (2016, February 25). Retrieved June 6, 2019, from New York Post website: https://nypost.com/2016/02/25/zoo-animals-are-starving-todeath-in-this-war-zone/

Top Sites in Turkey - Alexa. (n.d.). Retrieved June 16, 2019, from https://www. alexa.com/topsites/countries/TR

Torres, B. (2007). Making a Killing: The Political Economy of Animal Rights. Oakland, Edinburgh, West Virginia: AK Press.

van Dijk, T. A. (1991). Racism and the Press. London; New York: Routledge.

van Dijk, T. A. (1997). Discourse as Interaction in Society. In T. A. van Dijk (Ed.), 
Discourse as Social Interaction (pp. 1-37). London; Thousand Oaks; New Delhi: SAGE.

van Dijk, T. A. (1998). Ideology: A Multidisciplinary Approach. London; Thousand Oaks: Sage Publications.

van Dijk, T. A. (2000). Ideology and Discourse: A Multidisciplinary Introduction.

van Leeuwen, T. (2008). Discourse and Practice: New Tools for Critical Discourse Analysis. Oxford; New York: Oxford University Press.

Waldau, P. (2013). Animal Studies: An Introduction. New York: Oxford University Press.

Weitzenfeld, A., \& Joy, M. (2014). An Overview of Anthropocentrism, Humanism, and Speciecism in Critical Animal Theory. In A. J. Nocella II, J. Sorenson, K. Socha, \& A. Matsuoka (Eds.), Defining Critical Animal Studies: An Intersectional Social Justice Approach for Liberation. New York: Peter Lang Inc.

Wodak, R. (Ed.). (1989). Language, Power and Ideology: Studies in Political Discourse. Amsterdam; Philadelphia: John Benjamins Publishing Company.

Wodak, R., \& Meyer, M. (Eds.). (2001). Methods of Critical Discourse Analysis. London; Thousand Oaks: SAGE.

Yaban Hayatı Dairesi - Belge, Bilgi, Haber, Duyuru Köşesi. (n.d.). Retrieved June 7, 2019, from Doğa Koruma ve Milli Parklar Genel Müdürlüğü website: http:// www3.milliparklar.gov.tr/AnaSayfa/yabanHayatiDairesi/yh_belgeler.aspx?sflan$g=\operatorname{tr}$

Yılmaz, I. G. (2017, April 2). Fikir Karargahı - Türkiye'deki Günlük Gazeteler ve Haber Sitelerine Dair Sayısal/ Siyasal Veriler. Retrieved June 8, 2019, from Fikir Karargahı website: http://www. fikirkarargahi.com/turkiyede-gunluk-gazeteler-ve-haber-sitelerine-dair-sayisal-veriler/ 
